\title{
Integrating Social Constructivism and Personal Construct Psychology Approaches: A Discourse Perspective
}

\author{
Fella Yorlanda \\ U-Raise Academy, Pekanbaru, Indonesia \\ fyorlanda@gmail.com
}

\section{ARTICLE HISTORY}

Received : 2019-06-29

Revised : 2019-08-25

Accepted : 2019-08-31

\section{KEYWORDS}

Depth psychology

Discourse psychology

Social constructivism

Personal construct psychology

\begin{abstract}
This paper outlines the key features of discourse and psychological construct Psychology (PCP) in the past decades. This library research constructs its 59 related studies have been downloaded from the Google Scholar databases. The analysis in this study sees the crossroads between social constructivism and personal construct psychology (PCP) are increasingly being employs during the past decades. This convention is not only appropriate but seems to need each other. When construction sees cognition not as a person by any means leading to "behind" behaviour, but the configuration of the mind and sense that occur in action, the social context of the act that arises as an interest. At the same time, how cultural ideas or practices or "discourses" manifested in individuals and their actions, is very important. Therefore this study jump into conclusions that the discourse of psychology offers an opportunity to develop a coherent mix of social constituent ideas around the discourse, with PCP.
\end{abstract}

\section{Introduction}

From years to years there are lip services that are paid to the psychologist's need to take into account the 'so-official context' of behaviour. In practice, there has been a lack of theoretical and methodological suggestions for achieving this commendable goal. In this paper, it is suggested that we may imagine ourselves both as social and individual, as physicists who regard light as simultaneous waves and particles. What we see depends on how and why we see it. A big-picture needs a high vision, and strong theory can provide this. One of the consequences of this view is that we are allowed to see that people composed of different and sometimes contradictory elements are determined by various cultural demands, their experiences made through particular social life. In short, we mould ourselves living from social resources - discourse - around us.

Vivien Burr $(1995,2003)$ has been at the forefront in providing the discourse of terrorizing, socialconstructed accounts to understand psychological phenomena. As he notes, the danger in shifting in understanding is that of scope for interpersonal interference may appear minimized, and it may seem that people are becoming a tool of language and social practice, lacking institutions. This is the reason why psychological theorists should be fully aware of some of the things to say about the reciprocity process in which social forces make the individual experience and become a habit, but are modified and altered by individual actions. This brings us to the psychology of building a personal George Kelly (1955). It is said that Kelly's personality account is suitable to add to the discourse approach. I call this theoretical account as an integrated 'discourse of psychology '. This dictates discursive practice and the individual 'interpret' (sense of manufacture) as different aspects of the same phenomenon. Here is the development of this idea. Both elements are founded on the use of language.

\section{Methodology}

This library research constructs its 70 related studies have been downloaded from the Google Scholar databases. The Google Scholar database was chosen to search for related studies for this review as it is a free and wide database and provides a variety of information covering multiple authoritative sources. It is easily accessible and indexed literature through various disciplines. Search is limited to a twenty-year period from 1998 to 2018, in choosing related studies for review. Keywords such as Discourse and Personal Construct Approaches are used to explore. Of the 70 studies, 11 studies were eliminated in the absence of a novelty.

\section{Findings and Discussion}

Some of the important findings that this study needs to share as it reveals in this study.

\subsection{Language and Discourse}

A major shift in foodstuff psychological investigations has occurred for twenty years. This shift challenges assumptions that are held both inside and outside of psychology, about the nature of people, and the right focus to learn them. Above all, this shift is characterized by a focus on language and meaning. Therefore, a study that linked with language and meaning were needed to help us understand this 
discourse. Integrating discourse and personal construct approaches can be seen from social constructivism and personal construct psychology (PCP). However, this study decided to see this as only a discourse or discursive practice. Discourse can be referred to as the pattern of speech and how the language, dialect, and statements received are used in a particular society. Discourse as the subject the study views the discourse between people who share the same speech convention. In addition, the discourse refers to the linguistic use of language as a way of understanding interactions in social contexts, in particular, the analysis occurring connected speech or written discourse "Dakowska (2001) in Hamuddin (2012).

Further, "As part of this shift, language is seen as not only representing the world, or functioning as a mirror that reflects the meaning people have in their minds" (Davies and Harre, 199 0). Conversely, the social condition of circumstances in which it is possible to have a general meaning that could be conveyed in the language gives rise to the most likely form of speech or writing. The forms of language, in turn, rising the meaning and understanding available to people to use, so "what we can know is what can be said," (Walker, 1988, p.74). Further, in this view, "psychological phenomena are not things 'in' somebody that psychologists can find or express, but are created by the actual language used to describe them, and the meanings that become attached to that use" (Shotter, 1993). "This phenomenon has the reality of society, and it is a mistake to believe that they have their origins in the heads of individuals" (Burman and Parker, 1993).

The centre for this argument is the notion that our speech and writing are built from existing cultural resources that only make sense in an interpersonal context. These resources are sometimes referred to as 'discourse'. One does not create those resources; they borrow and refashioned for their own purposes in every instantiation of language use (Marmandatory and Raabe, 1993).

Foucault $(1972,1977,1980,1981)$ studied the ways in which, and under what conditions, various forms of knowledge emerged historically from the practice of so-official and cultural settings. He argues that meaning and knowledge are not universal, circumstances, and 'real', but always local, constructed and contested. For Foucault, knowledge is the product of the real social formations located within, and in-evitable linked to, the network of power relations. Foucault proposes that discourse includes both symbolic application of meaning in the text of the text in action and the conventions and relationships that make up the human life forms in which this interaction takes place (what we might also call 'culture'). He argues that discourse can be treated as "systematic practice of shaping the objects they speak" (1972, p.49). This definition has some important consequences. It's a layer that objects - like 'self' - do not exist independently of the way in which they talk about in the language. Indeed they only come to exist as objects when they are given existence through discourses. Furthermore, the emphasis on discourse as a practice implies that the discourse itself does not have some high reality. It is not an object, but a process related to human action. The discursive practice is the use of sign systems directed at or multiple human interactions. Any use of the language itself is a form of action realized.

This account connects behaviour, language and meaning in an interesting way. For discourse abounds in our social world. One of the experiences of things like gender, race, class and identity through the average is available in discourse (Davies and Harre, 1990). So the subjective experience itself is generated through the construction of possible realities, media created by the available discourses. The discourse of deciding things about the way the world is, and the things that are then brought to be given as terms and concepts of discourse used in the language. For example, the idea of human essence is more or less fixed, human nature, determined in many efficient and modern discourses. But discourse not only describes the phenomenon. They bring them into the vision (Parker, 1992a). In this way discourse the constitutive experience.

The discourse "permits and provokes the phenomenon we call cognition, and which we learn, in contemporary western culture, to channel into a single mind," (Parker, 1992a, p.92). They have historically evolved and made important parts of the cultural sense, as well as the arrangement of the operation of miscellaneous institutions including law, academia, politics, and popular culture. As Davies and Harre put it: "To know nothing is to know in terms of one or more discourses" (1990, p.45). In psychology, an established approach to discourses "demands a shift in the topic of a measured behaviour with the dynamics of meaning," (Parker, 1992a, p.69). It is compatible with psychology as a discipline dedicated to understanding human meaning and action, through which it is concerned with "the diversity of discourse we live and shaped by, use and use by" (Mair, 1989b, page 2).

\subsection{Social Construction}

The approach of discourse to embrace, and contribute, the broader canvas of social constructivism. It is a dedicated movement with many origins and one that has had an influence on psychology (Ger gene, 1985; Burr, 1995). A social constructionist states that all the so-called social reality constructs, 'imaginary', contested, and lies in certain historical conditions. The assumption of a stable and good reality is formed outside of 
appearance (which can be felt through the abstract set of principles or by expressing the 'true' inner soul) must instead be replaced by that of "vaguely, only partially determined, stable, open to further specifications as a result of human, communicative activity "(Shotter, 1993, p.179). The focus is lacking on understanding how a person comes to operate in and knows, the real outer world around them. Instead, the emphasis is placed on how people relate to others and to their world, and then how that creates the reality. For Burr, constructive social critics also extend to reveal that psychological theorizing does not describe reality, but partial in becoming just one way to see the world among many, and reflects personal interests (Burr, 1995 \& 2003).

\subsection{Subjectivity}

Sampson (1989) argues that we do not start with two independent entities, individuals and societies, which are formed and set apart from each other and interact as if they were the other external ones. Instead, "society is and inhabits the essence of whatever passes for personality" (Sampson, 1988, p.4). In this case, each self presupposes a 'world' (Mair, 1989a). Discourse approach allows for the deconstruction of the modernist divide between individual and society. Beyond psychology, for example in society and political science, attempts have been made to marry socially with individuals, usually with the aid of psychoanalysis.

The concept of 'subjectivity' is central to this. This is a special notion that is not understood only as of the opposite of objectivity. Rather, it is identical to the subjective 'experience' but with a certain slope: the experience formed in the language by discourse. This will be used to indicate that 'objects' such as selfhood and individuality are built into a network of meanings. What a person is taken to be, and the quality and capacity owed to people, depends on the language used to describe them, and what might be said within the boundaries of the discourse.

So "the subject, sense of self, is a location built within the expressive sphere that finds sound through cluster attributes and responsibilities assigned to it as various objects" (Parker, 1992a, p.9). An 'individual' is an entity formed through or marked with, a variety of discursive practices in which he is given space to participate. The result can be considered as the way things seem to be somebody in relation to the discursive context. Such concepts go a long way to bridge the psychological split of individual societies, through the understanding of society as organized, 'giving birth' and given the realization by discourse, and at the same time through seeing their individual and psychological world as located 'claims' of identity are allowed to, and built-in, many shared life discourses.

\subsection{Fragmentation}

In the twentieth century, psychoanalysis has been in pairs of great criticisms of ideas developed as coherent, unified, and unfounded. It has been suggested that people are shared internally between different aspects of personality: between conscious and unconscious, and between competing impulses. With the discourse approach, rational idea, independent unity is also questioned, through the study of subjectivity fragments operating through different discourses. Internal conflict is not regarded as a sign of dissonance or am-bivalence in the emotional and cognitive apparatus of the individual, but the normal (and therefore psychological) discursive process. The complete framework in articulating issues. The point of fragmentation means that subjectivity is multiple, it refers to some discourse. This is sometimes referred to as 'divided subject' (Henriques, et al, 1984). Our identity is both continuous and discontinuous, in that we have a "great survival" (Davies and Harre, 1990, p.47).

\subsection{Positioning}

Another valuable tool that arises from an approach based on discourse and subjectivity is that of 'position'. As the top subjectivity discussion is suggested, while discourse is 'about' objects, it also 'contains' the subject (Parker, 1992a). That is, discourse makes available space or 'positions' where a particular type of self may be a step. The idea of 'positioning' gives recognition to the ways in which people are living with discursive practices. Subjectivity is generated through the use of discourse from a particular position. This is a far more useful concept than the more static idea of 'role' (Davies and Harre, 1990). This is the position with the discourse that produces the so-called experience. The position of 'psychotherapist' and 'client' governs the relationship in which sound utterances of particular ways. Similarly, the position of 'research psychologist' and 'experimental subject' writes two persons in discourse and conferring on them a different and relatively specific function and power.

The positioning concept "recognizes both the cultural power of discourse available to frame our experience and limit our behaviour while allowing space for people to actively engage with people of discourse and employ them in social situations" (Burr, 2003, p.113). Positioning, in turn, highlights the idea of fragmentation and what has come to be called a 'divided subject'. Fragmentation can be understood as a result of conflicts between different discursive positions that can be drawn at different times. Alternatively, the subject may be in a position (or use language) meaning simultaneously in a number of some potentially contradictory ways, depending on the various factors including other involved social actors and the particular context. 


\subsection{Ideology}

A 'productive' discourse. That is, they create the possibility of action and become. But they too exclude possibilities. They limit the way to represent and understand the social world, thereby blocking the view of things in an alternative way. They enable and limit, facilitate and limit what can be said, by whom, where and when (Parker, 1992a; Howarth, 2001). This limiting and enabling function of discursive practice means that discourse can be adapted for the effects of power relations. The contemporary social theory uses the term 'ideology' to refer to that relationship.

According to Althusser (196 8), "ideology discourse 'interpolates' or the subjects 'call' to position so as to achieve a certain effect of power ". In other words, an ideology builds a series of social positions that provide ways of giving meaning and representing reality. It thus offers a believable way of making sense of the experience. Ideology then becomes a label that identifies councils of meaning from meaning in a certain social context (Thom, 1984). Proces legitimisation, rationalisation, naturalization and justification are central to ideological means of work (historical silence and marginalization of women's experiences are examples). Ideology is thus tied to social institutions, as "Institutions are not only social life structures, they also limit what can be said, who can say that".

Ideology is not just about ideas or beliefs. It concernss the material life, practical and moral behaviour, and the existence of the body. As a series of relationships, ideology encourages social production and reproduction through the combined effects of the pre-existing circulation of discourses ('stories' of the world) with the exercise of power. Ideology allows certain groups to tell their narratives about the past to justification now (Said, 1993) while preventing other institutions from making history.

The depiction of ideology may give the impression that human beings have limited agency, that we all just 'experience' to a position in a rigid system in which we (e.g.) recognize ourselves, just waiting there is no room for freedom. There is indeed controversy here, and the tension between the construct approach and social constructionism on the subject (Warren, 2005). However, some of the most insightful ideological discussions can be found in the work of leading cleric Bob Connell (Connell, 1987, 1993, 1995, 2002). Writing in a gender context, Connell has outlined hegemonic views ideology, in which the individual is subject to "Emergent sets of pressures and possibilities in which the actual diversity of personality is composed" (Connell, 1987, p.224). The practice of social ideology and individual experience (different views across a set of processes) are potentially transformative. As Connell notes in discussing masculinity, one cannot become masculine in a certain way without "influencing the condition in which that form of masculinity arises; whether to reproduce them, intensify them, or subvert them "(1993, p.302). From this attitude, it is well-held that the subjects are 'used' discourse, and the discourse plays itself through the actions and inner world of individuals who identify themselves through the meaning of paragraphs, ideas and ideals. In other words, one is positioned in the discourse both by self, but also through the operation of power. Parker reveals this when he revises a Marx dictum: "'make' People of discourse, but not in their own discursive conditions" (1992a, p.32).

Ideological considerations allow us to examine psychological phenomena not in terms of truthseeking, but as a set of 'truths' held in place by language and power. Adding the ideology to the discourse of oeuvre psychology permits, more than anything else, understands that power relations get into the construction of what it means to be human in the first place, and into the possibilities of an imaginable world.

\subsection{Personality Theory}

Finally, as noted in the introduction, the discourse approach requires a 'compatible people' model with it (Parker, 1990). Without such a model, there is a danger that discourse accounts will tell us nothing about the uniqueness of human experience, or about the scope and degrees of their freedom. To "say that people negotiator positions, or that their subjectivity is formed by discourse say nothing about how these processes are supposed to operate" (Burr, 2003, p.180). We need to explain and understand this very real phenomenon. The model of the theorist generally employed to describe the discourse approach has been influenced by psychoanalysis. There are several reasons for this.

First, the subject's psychoanalysis is divided and fragmented and immediately draws into discursive accounts of subjectivity (Henriques et al., 1984). Second, poststructuralist and social constructionist traditions from which the study of psychological discourse have partially emerged, maintaining a loyal appeal with psychoanalysis, particularly of the Lacanian variety. In many cases, psycho-analogy deprivation seems to have been done with little examination of the weakness of this step, or other possibilities (Burr, 2003). An alternative does exist in the form of personal build psychology.

\subsection{Constructivist}

There are some recent explorations of how personal building psychology can be used to enhance an understanding of the social construction of knowledge and reality (Butt and Burr, 1994; Warren, 2004). In particular, Harre and Gillett (1994) have 
sketched out Kelly's reading of connecting personal construct thinking with discourse approaches in psychology; what follows interesting and expanding their accounts.

In keeping with the psychological discourse approach, Kelly believes that social psychology needs to be interpersonal psychology under the standings (Kenny, 1984). The construction of the emerging world is not through processing in the abstract and detached of the independent individual; they are the result of our interaction with the world, and we meet with around social structures and relationships. In this sense, such as the dialectic between subjectivity and discourse, there is a relapses relationship between people and events "not rigid or destructive force a person's perspective event, not flooding too passively of the person with the event" (Epting and Amerikaner $1980.58)$.

From here, there are some striking direct connections between psychology informed by discourse theory and personal construct theory. In the second, that means the decision is central. The construction metaphor is also common for both personal constructs and discourse approaches. It is a lesson that Kelly is even considered to use the term 'reconstruction' rather than therapy to describe what she is trying to do clinically (Fransella, 1985). Furthermore, Kelly 'seemed to be close to under psychology standing covenant with the perspective of emphasizing discourses the built-in nature and contingent meaning, whereby people see themselves as if they were 'really' the way the discourse describes them.

\subsection{Link Construction and Discourse}

Construction, such as discourse, create and limit new experiences. They determine what will be perceived as reality. They bring the phenomenon into being. Indeed construction can be seen as an effect or artefact of discourse. People make a 'private' discrimination state between the features of an event, but the Category-cuts they use and criteria to distinguish both are thoroughly discursive and thoroughly idiosyncratic. So it is a means to validate constructs. Someone "depends on and robs them of the available things in the discourse," (Harre and Gillet, 1994, p.140). Kelly himself admits that the influence of cultivation exists in one's construction system and 'limits the type of evidence in his [sic] exile,' (Kelly, 1955, p.693).

The resources for constructing a system of constructs are therefore always pre-existent, and carrying the meanings and outward effects of what these individuals mean by 'deprivation' of them. Similarly, psychological phenomena, being discursive, are connected to meanings and effects that go beyond the immediate occurrence of such phenomena. To construe yourself as 'depressed' does not provide insight into the 'right' state of a person's soul; it demonstrates the consciousness of the (relatively obscure) resources written in the contemporary discourse of mental illness, which is used to interpret, impose and thus bring existence to a person's form of existence manifested.

This view defies two conventional psychological assumptions: that there is a 'real' phenomenon (such as depression) to be recognized in people, and that there is a sure way to represent this phenomenon (e.g., through an 'accurate' model of depression). This assumption is replaced by the idea that all phenomena exist only insofar as they are brought into existence through discursive practices (i.e., through construing). This 'bringing forth' in the context of interactions thus constitutes both phenomena and their representations. Depression becomes the result of a network of people's meaning structures about themselves and the world (Rowe, 2004).

Kelly suggests that to interpret is to hear whispers of themes that resonate around us over and over. In other words, 'people personify themselves with socially embedded meanings' (Hoshmond, 1993, p.181). The psychological similarity to others is seen in terms of the general way of interpreting the world, which results from the common pool of discursive resources available. Reality is created by and through the practice of conversation (and therefore discursive) that people engage you in and do (Mair, 1989a; Shotter, 1993).

From here it is possible to distinguish that "selflocation in discourse is the key to understanding construction and through their personality. People adopt or commit to a particular position in the discourse that they ... inhabit" (Harre and Gillet, 1994, p.140). It directs attention to meaning or images in which people interpret their own identity.

In such an approach, the study of the mind can be seen as a way of understanding the phenomenon that arises when the discourse is represented in an individual positioned (and position of self) in relation to their discourse. The uniqueness of man is recorded, that every individual has a special or 'private' order of construction, with the discourse still inhabiting the heart of a self-defining construction conceived of one's 'essence'. The discourse of people views does not then need to find a different set of inner processes to explain the uniqueness of every human being, as each human being is unique in a way directly relevant to the psychological explanation. "Every human individual stands at a unique intersection point of discourse and human relations" (Harre and Gillet, 1994, p.132-3).

In short, people are 'coherent' entities for the former tents that they adopt various positions in different disc-entities and thus fashion for themselves a unique system of personal construction (Butt and 
Burr, 1994). The human understanding of self and the world thus involves the fluent in the discourse. This echo (1980) Wittgenstein's conception of knowledge is not as the accuracy of representation, but the problem of knowing one's way about. Self-knowledge becomes not so much deep-seated product probing of the soul, as a result of skill with discourse, know-how, understanding of what determines oneself (Gergen, 1989). Determine oneself (Gergen, 1989). It is also a con-firm why discourse is the right matter subject for psychology: "A lower conception of man and psychology ... fails to display the richness of the human mind and personality, which draws on the meaning and value specified in the discursive context "(Harre and Gillet, 1994. p.143).

\subsection{Back to ideology}

We can only ever learn what our construction system allows us to see in the events (Kenny, 1984). It provides a clear relationship with ideological operations. This helps in understanding how ideologies inhabit the essence of subjectivity by the things described in one way rather than in other ways. This is the under-emphasised part of Harre and Gillett's account. Kelly thinks that where one places yourself along the dimension of the construct is not as important as the fact that the construct has grown in the first place. Constructs come from discourses that can achieve certain ideological effects and are often sustained by ideological support. Experience is related to ideology because the discourse directly interprets along a certain line. In this case, people who are not so much 'dominated' by ideological forces, but discourse enters into the psychology of personal construction in other ways related to ideology. Kelly suggests that cultural orders and preferences are often construction validators. So not only does discourse provide resources for construing, but they are also a meaning in relation that anticipation is tested. For former tents whose ideology promotes social arrangements as 'normal' or 'natural', validate certain kinds of experiences and not others. Hence the contribution to the maintenance of a constructive system that at least partially serves ideological purposes.

\subsection{Positioning}

The notion of 'positioning' has found some elaboration in the context of personal construct theory. Salmon argues that the placement of people in relation to their world is the fundamental means by which they are defined: "If we see people as their incarnation experience, and as taking an attitude toward their lives, we can, I think, achieve a better understanding of what they do, because that is our position on our lives that governs the kind of post responsibility engagement for us "(1985, p. 181). Another way of saying this is that reality is built by 'translating' discourses into personal terms. In this way, good people are positioned and position themselves in discursive space (Burr, 2003). It is possible to read in Kelly the implicit view of his position when he says that "the use of constructs is a matter of choosing the door booth through which it passes" (1955, p.66). So we still need personal psychology, as the character and form of 'translation' allegedly unpredictable or predictable (again drawing on arguments for personal agents in the form of ideological hegemonic).

\subsection{Threat}

In building a personal theory of something defined as 'threatened' if it "makes us aware at some level of change is imminent in the way in which we see ourselves" (Fransella, 1983, p.92). This happens "every time we look at some level of consciousness, a change is imminent in some central personal commitment, in some cherished view of ourselves" (Fransella, 1983, p.92). In other words, the changes threatened when bringing awareness of the need to recons true our identity in some radical way. This awareness may be explicit but also at the very edge of the bottom up. It applies a strong account of strengthening identity and concepts such as gender, and adherence to construction certain personally discursive position. The clear implication of some form of change can be threatening to our core construction and threatened in the very ways and means by which we understand the world (Viney, 1993). Our familiar identity and world-known tend to be protected so that it remains 'story' about ourselves we are now safe. In turn, we feel better able to manage life often shifting and unstable.

Kelly theory is free of postulations about the drive, impulse and energy in (Kenny, 1984). People are not moved by the force in relation to which they are fitted if. They are driven by their own way of interpreting events and objects. People constantly in this process of movement. The 'Motivation' want to anticipate events as part of the making sense just to explain that the subject will adopt and maintain at least some subjects' positions. Kelly notion of 'threat' because it can help explain the persistent adherence to a certain position, and regularized the use of a particular discourse. In the self through social practice, one enter into a relationship with discourse "can act as powerful as a motive, defence, identification, commitment and fear" (Connell, 1987, p.223). It is this feature that 'fix' we as subjects in the context of the threat associated with radical alternative consciousness and the possibility of change.

There is security in limiting ourselves and accommodating to the world of pre-existing ideological and created us. So the power inserts itself into subjectivity, through the influence of sustainable destinations and the world anticipates a person's place in it. 


\subsection{Fragmentation and Subjectivity}

Account follow from this fragmentation. Indeed, one of the statements that Kelly offered as part of the formalization of the theory, the 'Fragmentation fair', marking a clear relationship to the 'divided the subject'. It states: A person may successively using the various subsystems of the inferential construction compatible with each other (Kelly, 1955). Or, in terms of discourse, one may, at different times, or even at the same time, be located in opposing positions in the social space, so that "each of themselves that may be internally contradictory or conflicting with other possible themselves located in a different storyline "(Davies and Harre, 1990, p.58-9).

In terms of the theory of subjectivity, it is clear that the idea of Kelly the person does not refer to the entities understood in isolation, but to the individual hypotheses about how being in connection with others. Construction postulation this underlines the central role, in stressing that we know ourselves with a sense of social space we occupy in relation to other institutions. This is entirely consistent with the view that "our subjective experience of ourselves, become child-per-we take ourselves to be, by their various subject positions ... that we take the discourse" (Burr, 2003, p. 120),

\subsection{Linking Discourse to Construct}

This study seen some of the researchers have proposed that the discursive practices can be seen as a resource for the ongoing elaboration of the construction system. At the same time, people were positioned or shaped in a particular way by people Practices. Build a personal approach involving understanding from their perspective, concerned with meaning and their construction. It is important, also, to the discourse of psychology (Shotter, 1990), and install a personal construct theory in psychology discourse account balances tendencies towards abstraction in analysing the operation of discourse.

Personal construct theory thus adding components to understanding successful human capable psychologist discourse. It helps to understand that the changes (which are always both personal and soofficial) appear as a recursive process that involves the reconstruction of the system of meaning in the discourse of change available through evolving material and cultural conditions. This is the kind of account 'structuration' social relationships (Gidnest, 1984; Cash 1996) in which the good that reproduces and transform social structures whenever the instantiates some aspects of the structures.

One of them is the second created by the social order, and create it. In this connection, it is possible to understand experience as mediated by the meaning provided through discourse, and the product of one's way to build a particular meeting. After all, what one is the result of the fact that they have a set of cumulative experience than others (Scholes, 1987)? In this case, we are creatures always 'in motion'.

The combination of discourse and construction also helps to imagine that the two are one, and what as 'psychological', is an achievement and accomplishment carry through simulant continuous process of public and private construction. It makes clear that "the power relations of society become constitutive principle dynamics personality through adopted as a personal project, acknowledged or not" (Connell, 1987, p.215).

\subsection{Limitations and tension}

Even so, things are a bit more complicated than has so far been described. A difficult problem concerns status 'verb constructions'. If the overall meaning of the discursive, what is the status of construct that is functional but not written in language? Can 'discursive resources' including an extra-linguistic entity, or can be written in the body of discourse? In fact, Foucault tries to make precisely that last point: "Power relations material can penetrate the body deeply, without depending on mediation representation of the subject itself" (Foucault, 1980, pp, 186).

So maybe the theory of discourse can learn from personal construct approach here. If you think the verdict may include somatic and physiological dimensions, then, given the desire to holds that discourse is the stuff of sense-making, it might pay to have an understanding of discourse as Encompass-ing these dimensions, as embodied creatures (Butt, 1998). It would still be possible to see discourse as historical and contingent, and to maintain that fear of dimensions in the meaning-making procedure is in the final instance linguistic companies. All of these provide a strong reminder that interprets not only a 'cognitive' while maintaining the notion that psychological reality of giving birth in the language as an experience is created through our discursive conversation practice.

Kelly also illuminates here. He said preverbal build "is one that continues to be used despite not having a consistent word symbols" (1955, p.564). So the verb construction may exist in the shift, playful relationship with language, and gave birth to the couple and a variety of ways.

One disadvantage alleged personal construct theory is that it fails to specify the conditions under which one constructs 'adopted' or made than others (Hall and Lindzey, 1978). Similarly, who could ask under what conditions a discourse chosen and not others. But maybe we have to stand in the room would have. This could be considered as space where freedom exists. This introduces uncertainty into a radical evolution of subjectivity (and therefore an 
openness to the possibility of social change), and also acknowledge that it is impossible to understand human life with a perfect cause and effect precision. Curiously, this same type of argument was recently made in respect of Neuroscience (Horgan, 1999).

\section{Conclusion}

After reviewing these 59 articles this study sees the crossroads between social constructivism and personal construct psychology (PCP) are increasingly being employs during the past decades. This convention is not only appropriate but seems to need each other. Discourse making positions and resources to interpret, the negotiating power of different effects at different positions in which interpreting takes place. At the same time, how cultural ideas or practices or "discourses" manifested in individuals and their actions, is very important. Therefore this study jump into conclusions that the discourse of psychology offers an opportunity to develop a coherent mix of social constituent ideas around the discourse, with PCP.

\section{Acknowledgement}

This research was supported by the LPPM Universitas Lancang Kuning, Pekanbaru. Therefore, the authors would like to express their sincere gratitude. Any opinions, findings, and conclusions or recommendations expressed in this material are those of the authors and do not necessarily reflect the views of the respected institution.

\section{References}

Althusser, L. (1968). Lenin and Philosophy. London: Monthly Review Press.

Burman, E. \& Parker, I. (1993). Introduction -discourse analysis: The turn to the text, in E. Burman \& I. Parker (eds) Discourse Analytic Research: Repertoires and Readings of Texts in Action (pp1-13). London: Routledge.

Burr, V. (1995). An introduction to social construction-ism. London: Routledge.

Burr, V. (2003). Social constructionism (2nd edition). London: Routledge.

Butt, T. \& Burr, V. (1994). The person in social constructionism. Paper presented at the Conference of the British Psychological Society, Cambridge.

Butt, T. (1998). Sociality and embodiment. Journal of Constructivist Psychology, 11, 105-116.

Butt, T. (2004). Understanding, explanation, and personal constructs. Personal Construct Theory \& Prac-tice, 1, 21-27.
Cash, J. (1996). Identity, ideology and conflict: The structuration of politics in Northern Ireland. Cambridge: Cambridge University Press.

Connell, R. (1987). Gender and Power. Sydney, Allen and Unwin.

Connell, R. (1993) The big picture: Masculinities in recent world history, Theory and Society, 22: 597-623.

Connell, R. (1995) Masculinities. Sydney: Allen and Unwin.

Connell, R. (2002). Gender. Cambridge: Blackwell.

Davies, B. \& Harre, R. (1990). Positioning: The discursive production of selves, Journal for the Theory of Social Behaviour. 20, 43-63.

Epting, F. \& Amerikaner, M. (1980). Optimal functioning: A personal construct approach, in A. Landfield

Foucault, M. (1972). The archaeology of knowledge. London: Tavistock.

Foucault, M. (1977). Language, counter-memory, practice. Ithaca: Cornell University Press.

Foucault, M. (1979). Discipline and punish: The birth of the prison. New York: Random House.

Foucault, M. (1980). Power/knowledge: Selected interviews and other writings 1972-77. Hassocks: Harvester Press.

Foucault, M. (1981). The history of sexuality. Vol. I. Harmondsworth: Penguin.

Fransella, F. (1983). Threat and the scientist, in G. Breakwell (ed), Threatened identities (pp 91-104). New York: Wiley.

Fransella, F. (1985). Individual psychotherapy, in E. Button (ed), Personal construct theory and mental health: Theory. research and practice (pp 277301). London: Croom Helm.

Gergen, K. (1985) The social constructionist movement in modern psychology, American Psychologist, 40: 266-275.

Gergen, K. (1989). Warranting voice and the elaboration of the self, in J. Shotter \& K. Gergen (eds) Texts of identity (pp 70-81). London: Sage.

Giddens, A. (1984). The constitution of society. Cambridge: Polity.

Hall, C. \& Lindzey, G. (1978). Theories of personality (3rd edition). Chichester: Wiley.

Hamuddin, B. (2012). A comparative study of politeness strategies in economic journals (Doctoral dissertation, University of Malaya). 
Hamuddin, B. (2015). DISCOURSE ON MEDIA: Bringing Hot News into ELT's Classroom Discussion. Proceedings of ISELT FBS Universitas Negeri Padang, 3, 87-95.

Hamuddin, B., \& Noor, F. N. M. (2015, August).A Closer Look on Politeness Strategies in Malaysian Economic Journal.In 2nd INTERNATIONAL SEMINAR ON LINGUISTICS (p. 52).

Harre, R. \& Gillett, G. (1994). The discursive mind. London: Sage.

Henriques, J., Hollway, W., Urwin, E., Venn, C. \& Walkerdine, V. (1984). Changing the subject: Psychology, social regulation and subjectivity. London: Methuen.

Horgan, J. (1999). The undiscovered mind: How the human brain defies replication, medication and ex-planation. New York: Free Press.

Hoshmand, L. (1993). The personal narrative in the communal construction of self and life issues, in G. Neimeyer \& R. Neimeyer (eds) Constructivist assessment: A casebook (pp 179-205). London: Sage.

Howarth, D. (2001). Discourse. Buckingham: Open University Press.

Kelly, G. A. (1955). The psychology of personal constructs (2 vols.). New York: Norton.

Kelly, G. A. (1969). Man's construction of his alternatives, in B. Maher (ed) Clinical psychology and personality: Selected Papers of George Kelly (pp 69-93). New York: Wiley.

Kenny, V. (1984). An introduction to the personal con-struct psychology of George A. Kelly, Irish Journal of Psychotherapy, 3: 24-32.

Mair, M. (1977). Metaphors for living, in A. Landfield (ed), Nebraska Symposium on Motivation 1976 (pp 243-90). London: University of Nebraska Press.

Mair, M. (1989a). Between psychology and psychotherapy: A poetics of experience. London: Routledge.

Mair, M. (1989b). Psychology as a discipline of discourse, British Psychological Society Psychotherapy Section Newsletter, 7: 2-12.

Marshall, H. \& Raabe, B. (1993). Political discourse: Talking about nationalization and privatization, in E. Burman \& I. Parker (eds) Discourse analytic research: Repertoires and readings of texts in action (pp 35-51). London: Routledge.

Parker I. (1994). Discourse analysis, in P. Banister, E. Burman, I. Parker, M. Taylor \& C. Tindall (eds)
Qualitative Methods in Psychology (pp 92-107). Mil-ton Keynes: Open University Press.

Parker, I. (1990). Real things: Discourse, Context and practice, Philosophical Psychology, 3: 227-233.

Parker, I. (1992a). Discourse dynamics: Critical analysis for social and individual psychology. London: Routledge.

Parker, I. (1992b). Wild men, paper presented at the Psychoanalysis and the Public Sphere 6th Annual Conference, University of East London, October 30-31.

Rose, N. (1990). Psychology as 'social' science, in I. Parker \& J. Shotter (eds), Deconstructing social psychology (pp 103-116). London: Routledge.

Rowe, D. (2004). Depression: The way out of your prison 3rd edition. London: Brunner Routledge.

Said, E. (1993). Culture and imperialism. London: Chatto and Windus.

Salmon, P. (1985). Relations with the physical: An alternative reading of Kelly, in D. Bannister (ed), Issues and approaches in Personal Construct Theory (pp 173-182). London: Academic Press.

Sampson, E. (1989). Foundations for textual analysis of selfhood, in J. Shotter \& K. Gergen (eds) Texts of Identity (pp 1-19). London: Sage.

Scholes, R. (1987). Reading like a man, in . Jardine \& P. Smith (eds) Men in Feminism (pp 204-218). London: Methuen.

Shotter, J. (1990). Social individuality versus possessive individualism: The sounds of silence, in I. Parker \& J. Shotter (eds), Deconstructing Social Psychology (pp 153-169). London: Routledge.

Shotter, J. (1993). Conversational realities: Constructing life through language. London: Sage.

Thompson, J. (1984). Studies in the theory of ideology. Cambridge: Polity.

Threadgold, T. (1988). Language and gender, Australian Feminist Studies, 6 (Autumn): 41-70.

Viney, L. L. (1993). Listening to what my clients and I say: Content analysis categories and scales, in G. Neimeyer \& R.Neimeyer (eds) Constructivist Assessment (pp 104-142). London: Sage.

Walker, T. (1988). Whose discourse?, in S. Woolgar (ed), Knowledge and reflexivity (pp 55-80). London: Sage.

Warren, B. (2004). Construing constructionism: Some reflections on the tension between PCP and social constructionism. Personal Construct Theory \& Prac-tice, 1, 34-44. 
Wetherell, M. \& Potter, J. (1992). Mapping the language of racism: Discourse and the legitimation of exploitation. London: Harvester Wheatsheaf.

Wittgenstein, L. (1980). Remarks on the philosophy of psychology (Vol.1). Oxford: Basil Blackwell. 